\title{
A study of cortical and hippocampal NMDA and PCP receptors following selective cortical and subcortical lesions
}

\author{
William F. Maragos, J. Timothy Greenamyre, Dorothy C.M. Chu, John B. Penney and \\ Anne B. Young \\ Department of Neurology, University of Michigan, Ann Arbor, MI 48104 (U.S.A.)
}

(Accepted 31 July 1990)

Key words: Quisqualate; N-Methyl-D-aspartate; Phencyclidine; Autoradiography; Dentate gyrus; Cerebral cortex; Lesion

\begin{abstract}
The neuronal localization of glutamate and phencyclidine (PCP) receptors was evaluated in the cerebral cortex and hippocampal formation of rat CNS using quantitative autoradiography. Scatchard analysis of $\left[{ }^{3} \mathrm{H}\right]$ glutamate binding in the cortex (layers I and II and V and VI) showed no difference in the total number of binding sites $\left(B_{\max }\right)$ or apparent affinity $\left(K_{\mathrm{d}}\right) 1$ week, 1 month and 2 months following unilateral ibotenate lesions to nucleus basalis of Meynert (nbM) compared to the non-lesioned side. Quisqualic acid displacement of $\left[{ }^{3} \mathrm{H}\right] \mathrm{glutamate}$ in layers $\mathrm{I}$ and II, 1 week following nbM destruction, revealed both high- and low-affinity binding sites (representing the quisqualate (QA) and $N$-methyl-D-aspartate (NMDA) sites, respectively). Compared to the control side, there was no difference in binding parameters for either of the receptor sites. In similarly lesioned animals, the NMDA receptor was specifically labelled with $\left[{ }^{3} \mathrm{H}\right]$ glutamate and the associated PCP receptor labelled with $\left.{ }^{3} \mathrm{H}\right] N-\left(1-\left[2\right.\right.$-thienyl]cyclohexyl)3,4-piperidine $\left(\left[{ }^{3} \mathrm{H}\right] \mathrm{TCP}\right)$ in adjacent brain sections. For both receptors, there was no change in the total number of binding sites in the cortex following destruction of nbM. On the other hand, virtually all binding to NMDA and PCP receptors was eliminated following chemical destruction of intrinsic cortical neurons. These results suggest that the NMDA/PCP receptor complex does not exist on the terminals of cortical cholinergic afferents. One week after knife cuts of the glutamatergic entorhinal pathway to the hippocampal formation only an approximate $10 \%$ reduction of NMDA and PCP receptors was seen in the dentate gyrus. Conversely, selective destruction of the dentate granule cells using colchicine caused a near identical loss of NMDA and PCP receptors (84\% vs $92 \%$ respectively). It is concluded from these experiments that glutamate and PCP receptors exist almost exclusively on neurons intrinsic to the hippocampal formation and that no more than 10\% of NMDA and PCP receptors exist as autoreceptors on glutamatergic terminals.
\end{abstract}

\section{INTRODUCTION}

Glutamate is a major excitatory neurotransmitter in the mammalian central nervous system which activates at least 4 receptor subtypes ${ }^{75}$. Due to the availability of selective antagonists for experimental analysis, the $N$ methyl-D-aspartate (NMDA) receptor has been most thoroughly investigated. NMDA receptors occur in highest density in subregions of the hippocampal formation and in layers I and II of the cerebral cortex ${ }^{19,45}$. Activation of this receptor seems to be necessary for the induction of long-term potentiation ${ }^{24,46}$ and may be important in the development of seizures ${ }^{10,15,26}$ as well as neuronal destruction caused by hypoxia/ischemia ${ }^{23,58,69}$ and hypoglycemia ${ }^{74}$. NMDA receptors have also been shown to be decreased in the cerebral cortex ${ }^{20}$ and hippocampal formation ${ }^{21,54}$ of patients with dementia of the Alzheimer type (DAT).

The dissociative anesthetics (e.g. phencyclidine and ketamine) are a unique class of drugs which are thought to interact with the NMDA receptor. Electrophysiologically, these drugs have been shown to block the activation of the NMDA receptor in the spinal cord and cortex ${ }^{13,33,65}$. The dissociative anesthetics also inhibit the induction of long-term potentiation ${ }^{62}$ and NMDA-induced neuronal degeneration ${ }^{50}$. Drugs like PCP and ketamine appear to act as non-competitive inhibitors of the NMDA receptor ${ }^{25,41}$ and probably exert their effects at an allosteric site on the receptor complex ${ }^{35}$. Support for this concept comes from binding studies demonstrating that the dissociative anesthetic binding sites possess a distribution identical to that of the NMDA receptor in the rat forebrain ${ }^{40}$. The NMDA receptor complex has also been solubilized from rat and pig brains ${ }^{42}$ and expressed in Xenopus oocytes injected with either rat brain $^{30,67}$ or mouse neuroblastoma-Chinese hamster brain hybrid ${ }^{32}$ mRNA. In both instances the NMDA receptor complex displayed pharmacological and physiological properties similar to those seen in both membrane and tissue preparations.

Correspondence: A.B. Young, The University of Michigan, Neuroscience Laboratory Building, 1103 East Huron Street, Ann Arbor, MI, 48104-1687, U.S.A. 
While much data has recently been gathered concerning the pharmacological and behavioral interactions between the two sites, little is known about their neuronal localization. In the cerebral cortex, NMDA stimulates the release of acetylcholine ${ }^{34}$, possibly by stimulation of the terminals of neurons originating from the subcortical nucleus basalis of Meynert (nbM) ${ }^{27,70}$. Drugs like PCP block this enhancement ${ }^{34}$. In the hippocampus, NMDA receptors may exist presynaptically on glutamatergic terminals ${ }^{6,8}$.

In order to determine whether glutamate and PCP receptors are located on the presynaptic terminals of cholinergic or glutamatergic neurons or on postsynaptic elements intrinsic to the cortex and hippocampus, we have conducted autoradiography of both $\left[{ }^{3} \mathrm{H}\right]$ glutamate binding to NMDA receptors and $\left[{ }^{3} \mathrm{H}\right] \mathrm{TCP}$ binding to dissociative anesthetic sites in a series of experimentally lesioned animals. In one group, animals received unilateral ibotenic acid lesions to nbM and binding to both receptors was analyzed in cortex. In the second group of animals, axon sparing lesions using ibotenic acid were made in the cortical projection zones of $\mathrm{nbM}$ and subsequent analysis of receptor binding in the cortex was carried out. We have also lesioned the glutamatergic entorhinodentate pathway ${ }^{72}$, since this is a unidirectional projection $^{60,63}$ and any subsequent decrease in receptor binding in the dentate gyrus would imply a presynaptic localization of the receptor complex. Conversely, we have destroyed granule cells of the dentate gyrus, using the alkaloid colchicine, to determine what proportion of receptors are postsynaptic. Colchicine disrupts microtubular formation and, in the hippocampal formation, selectively destroys granule cells ${ }^{18}$.

\section{MATERIALS AND METHODS}

\section{Surgery}

Adult male Sprague-Dawley rats weighing approximately $200 \mathrm{~g}$ were used in all surgical procedures. Animals were anesthetized with xylazine $(5 \mathrm{mg} / \mathrm{kg})$ and ketamine $(80 \mathrm{mg} / \mathrm{kg})$ and surgery conducted with the animal's head secured firmly in a Kopf stereotaxic apparatus. For all surgical procedures, the incisor bar was $2.4 \mathrm{~mm}$ below the intra-aural plane.

\section{Nucleus basalis lesions}

Following placement of the animal in the stereotaxic apparatus, the skull was exposed, and a small burr hole was made with a dental drill. After removing the bone chip and incising the dura, a 30 gauge flat-tipped cannula was lowered into the brain. Ibotenic acid (10 $\mu \mathrm{g} / \mu \mathrm{l}$ dissolved in distilled water and adjusted to $\mathrm{pH} 7.4$ with $\mathrm{NaOH}$ ) was infused at a rate of $1 \mu \mathrm{l}$ per $8 \mathrm{~min} 20 \mathrm{~s}$. Each animal received a $0.5 \mu \mathrm{l}(31.6 \mathrm{nmol})$ injection to $\mathrm{nbM}$. Some animals received an additional $0.5 \mu \mathrm{l}$ injection of ibotenate into the anterior continuation of nucleus basalis at the level of the magnocellular preoptic nucleus. Coordinates for $\mathrm{nbM}$ were $1 \mathrm{~mm}$ posterior and $2.4 \mathrm{~mm}$ lateral to bregma and $6.6 \mathrm{~mm}$ ventral to the surface of the brain. Coordinates for magnocellular preoptic nucleus were $0.4 \mathrm{~mm}$ posterior and 2.4 $\mathrm{mm}$ lateral to bregma and $8.0 \mathrm{~mm}$ ventral to the surface of the brain.
A group of 8 rats received sham lesions by lowering the cannula into $\mathrm{nbM}$ and infusing $0.5 \mu \mathrm{l}$ of $0.9 \%$ saline. Animals were allowed to survive 1 week, 1 month, or 2 months at which time they were decapitated and their brains rapidly removed. The brains were quickly frozen on dry ice and stored at $-70{ }^{\circ} \mathrm{C}$ until use.

\section{Cortical lesions}

A small hole was drilled $5 \mathrm{~mm}$ lateral to bregma. The dura was incised and a 30 gauge flat-tipped cannula was lowered $2 \mathrm{~mm}$ into the brain. Ibotenic acid $\left(1 \mu \mathrm{g} / \mu \mathrm{l}\right.$ dissolved in distilled $\mathrm{H}_{2} \mathrm{O}$ and adjusted to $\mathrm{pH} 7.4$ with $\mathrm{NaOH}$ ) was infused at a rate of $1 \mu \mathrm{l}$ per 8 $\min 20 \mathrm{~s}$. Each animal received two $0.375 \mu \mathrm{l}$ injections $(2.37 \mathrm{nmol}$ each), one $0.0 \mathrm{~mm}$ and the other $1.5 \mathrm{~mm}$ posterior to bregma. Following a 1 week survival period, animals were killed, their brains removed and frozen until use.

\section{Entorhinal knife cuts}

As with nbM-lesioned animals, rats were anesthetized, placed in a stereotaxic apparatus, an incision was made, and the fascia and muscle were retracted. A trench was then drilled in the skull $7 \mathrm{~mm}$ posterior to bregma extending from near the midline to the origin of the temporalis muscle. A razor blade approximately $2 \mathrm{~mm}$ wide was lowered $6 \mathrm{~mm}$ beneath the surface of the brain and moved from the midline to the lateral surface of the brain to cut the angular bundle and sever the fibers of the perforant pathway, as described by Gibbs et al. ${ }^{17}$. In this study the contralateral hippocampus served as control. Animals survived for 1 week at which time they were decapitated, their brains removed, frozen quickly on dry ice and stored at $-70^{\circ} \mathrm{C}$.

\section{Dentate gyrus lesions}

Surgical preparations were carried out as previously described. Following removal of the bone chip the dura was incised. A 30 gauge flat-tipped cannula was lowered into the brain, and colchicine, at a concentration of $5 \mu \mathrm{g} / \mu \mathrm{l}$ (dissolved in distilled water and adjusted to $\mathrm{pH} 7.4$ ), was infused at a rate of $1 \mu \mathrm{l}$ per $8 \mathrm{~min}$ and $20 \mathrm{~s}$. Each animal received two $0.5 \mu \mathrm{l}$ injections ( $12.5 \mathrm{nmol}$ total) of colchicine to the dentate gyrus. A rostral lesion was placed $3.4 \mathrm{~mm}$ posterior and 1.1 $\mathrm{mm}$ lateral to bregma and $3.8 \mathrm{~mm}$ ventral to the surface of the cortex. A caudal lesion was made $4.3 \mathrm{~mm}$ posterior and $2.0 \mathrm{~mm}$ lateral to bregma and $3.7 \mathrm{~mm}$ below the cortical surface. In this study, animals were allowed to survive for 1 week, then killed and their brains removed and frozen at $-70^{\circ} \mathrm{C}$ until assayed.

\section{$\left.{ }^{3} \mathrm{H}\right]$ Glutamate incubation}

On the day of the experiment, the frozen brains were mounted on cryostat chucks and equilibrated in the cryostat for one half hour prior to cutting. Sections $(20 \mu \mathrm{M})$ were then cut and thaw-mounted onto gelatin-coated slides. Slides were prewashed for $30 \mathrm{~min}$ in either ice-cold $50 \mathrm{mM}$ Tris- $\mathrm{HCl}$ buffer with $2.5 \mathrm{mM} \mathrm{CaCl}_{2}, \mathrm{pH} 7.4$ or $50 \mathrm{mM}$ Tris-acetate, $\mathrm{pH} 7.4$ and then air dried. Detailed saturation and displacement studies of $\left[{ }^{3} \mathrm{H}\right]$ glutamate binding were carried out on all except 14 of the nbM-lesioned brains (see below). Saturation studies were carried out in $50 \mathrm{mM}$ Tris- $\mathrm{HCl}$ buffer $\mathrm{pH} 7.4$ with $2.5 \mathrm{mM} \mathrm{CaCl}_{2}$ to determine total $\mathrm{L}-\left[{ }^{3} \mathrm{H}\right]$ glutamate binding and

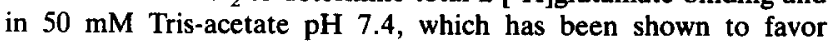
binding to the NMDA receptor ${ }^{19}$. Sections were placed in containers with $10 \mathrm{ml}$ buffer containing $45 \mathrm{nM} \mathrm{L}-\left[{ }^{3} \mathrm{H}\right.$ )glutamate $(22$ $\mathrm{Ci} / \mathrm{mmol}$, Amersham) and varying concentrations of non-radioactive glutamate ranging from $25 \mathrm{nM}$ to $10 \mu \mathrm{M}$. For displacement studies, slides were placed in containers with $10 \mathrm{ml}$ of $50 \mathrm{mM}$ Tris- $\mathrm{HCl}$ buffer $\mathrm{pH} 7.4$ with $2.5 \mathrm{mM} \mathrm{CaCl}_{2}, 200 \mathrm{nM}_{\mathrm{L}}-\left[{ }^{3} \mathrm{H}\right]$ glutamate (spec. act. of $5.23 \mathrm{Ci} / \mathrm{mmol}$ ) and varying concentrations of quisqualic acid ranging from $1 \mathrm{nM}$ to $1 \mathrm{mM}$.

In $8 \mathrm{nbM}$-lesioned brains and brains with cortical, entorhinal and dentate lesions, NMDA receptor density was determined in sections

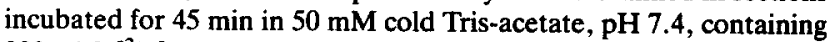
$200 \mathrm{nM}\left[{ }^{3} \mathrm{H}\right]$ glutamate $(5.23 \mathrm{Ci} / \mathrm{mmol}$, Amersham). Non-specific binding was determined in the presence of $1 \mathrm{mM}$ unlabeled glutamate. 
All sections were incubated in duplicate. Following incubation the slides were rapidly rinsed 3 times with $3 \mathrm{ml}$ of the appropriate ice-cold buffer, followed by one rinse with a solution of cold glutaraldehyde and acetone $(1: 19 \mathrm{v} / \mathrm{v})$ and rapidly dried under a stream of heated air. The total rinse time in this assay did not exceed $10 \mathrm{~s}$

\section{$\left[{ }^{3} \mathrm{H}\right] T C P$ incubations}

For $\left[{ }^{3} \mathrm{H}\right] \mathrm{TCP}$ binding, sections adjacent to those used for single point NMDA receptor determinations were used. Sections were

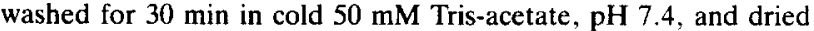
Sections were then incubated for $45 \mathrm{~min}$ in the same buffer at $4{ }^{\circ} \mathrm{C}$ containing $1 \mathrm{mM}$ magnesium acetate and $20 \mathrm{nM}\left[{ }^{3} \mathrm{H}\right] \mathrm{TCP}(40$ $\mathrm{Ci} / \mathrm{mmol}$, New England Nuclear). Magnesium acetate was added to the incubation medium, as this has been shown to enhance $\left[{ }^{3} \mathrm{H}\right] \mathrm{TCP}$ binding ${ }^{7}$. Non-specific binding was determined by incubating sections with $\left[{ }^{3} \mathrm{H}\right] \mathrm{TCP}$ in the presence of $20 \mu \mathrm{M}$ unlabeled PCP. All sections were incubated in duplicate. Following incubation, sections were washed 3 times, 1 min each in cold buffer and rapidly dried

\section{Autoradiography and data analysis}

Sections were placed in an X-ray cassette and apposed to a piece of Ultrofilm $3 \mathrm{H}$ (LKB). A complete set of radioactive standards was co-exposed with each film. Following a 2 week exposure period at $4{ }^{\circ} \mathrm{C}$, films were developed in D19 (Kodak), fixed and dried Autoradiographic analysis was carried out using a previously described method $^{51}$. At least 15 densitometric readings were taken from each area of interest on each autoradiogram section. Anatomical correlations were determined using the atlases of Paxinos and Watson ${ }^{53}$ and of Zilles ${ }^{76}$. Scatchard curves were generated from saturation data using the program LIGAND ${ }^{47}$. Quisqualate displacement curves were analyzed using the LIGAND program also. Readings from each series of lesioned animals were averaged and compared to the non-lesioned side using Student's $t$-test.

\section{Acetylcholinesterase histochemistry and choline acetyltransferase} assays

In 6 nbM-lesioned brains, the frontal poles were dissected and assayed for choline acetyltransferase activity (ChAT) according to the method of Fonnum ${ }^{16}$. Briefly, brain tissue homogenates were prepared $(5 \%, \mathrm{w} / \mathrm{v})$ and the enzyme liberated with $0.5 \%$ Triton $X-100$. Samples of the homogenate were then incubated in the presence of $\left[{ }^{14} \mathrm{C}\right]$ acetyl-coenzyme-A (acetyl-CoA) and choline bromide for $15 \mathrm{~min}$ at $37^{\circ} \mathrm{C}$. The reaction was stopped by rapidly chilling the incubation tubes and adding $5 \mathrm{ml}$ cold phosphate buffer to each tube. The reaction mixtures were added to scintillation vials containing toluene, acetonitrile and sodium tetraphenyl boron and agitated gently to extract the $\left[{ }^{14} \mathrm{C}\right]$ acetylcholine reaction product into the organic phase. The amount of radioactivity in the organic layer was then counted in a Beckman LS8100 scintillation counter Since water does not function as a scintillant, the $\left[{ }^{14} \mathrm{C}\right]$ acetyl-CoA that remained in the aqueous layer was not counted. The number of $\mathrm{nmol}$ of $\left[{ }^{14} \mathrm{C}\right]$ acetylcholine produced per $\mathrm{mg}$ protein per hour was then calculated.

In nbM-lesioned brains in which detailed saturation and displacement studies were carried out and in brains which had received

\section{TABLE}

Choline acetyltransferase activity in frontal pole of $n b M$-lesioned rats*

Values are means \pm S.E.M.

\begin{tabular}{lll} 
& $\begin{array}{l}\text { nmol substrate/ } \\
\text { hr/mg protein }\end{array}$ & $\begin{array}{l}\% \\
\text { reduction }\end{array}$ \\
\hline $\begin{array}{l}\text { Non-lesioned side } \\
\text { Lesioned side }\end{array}$ & $0.259 \pm 0.0045$ & - \\
\hline${ }^{*} n=6 ;{ }^{* *} P<0.0005$. & $0.105 \pm 0.025$ & $62^{* *}$ \\
\hline
\end{tabular}

ibotenate lesions to the cortex, 2-4 cryostat sections were obtained through the receptor assay region and processed for acetylcholinesterase (AChE) histochemistry ${ }^{29}$. Sections were washed for $1 \mathrm{~h}$ in cold $0.9 \%$ saline and rinsed with distilled water. Sections were then incubated for $3 \mathrm{~h}$ at $37^{\circ} \mathrm{C}$ in Tris-maleate buffer with acetylthiocholine as substrate. $\mathrm{CuSO}_{4}$ was included in the reaction mixture to complex with the liberated thiocholine. This copper-choline complex was stained with ammonium sulfate. Following the incubation, slides were rinsed in distilled water, dehydrated and coverslipped with D.P.X. (BDH Chemicals). Analysis of stained tissue was carried out using a Leitz SM LUX microscope.

\section{RESULTS}

\section{Nucleus basalis lesions}

Verification of nbM lesions at all time points was carried out by several tests. In animals in which frontal poles were dissected and assayed for ChAT, enzyme activity was reduced by $62 \%$ on the lesioned side (Table I). The extensive reduction of ChAT activity in the frontal poles did not, however, ensure a loss of cholinergic innervation in the somatosensory cortex through which sections were taken for autoradiography. To determine the extent of cholinergic loss in this region, every tenth cryostat section through the region was stained for AChE. A total of approximately 4 sections from each animal were stained in this manner.

Animals receiving single unilateral ibotenic acid injections to nbM displayed marked depletion of $\mathrm{AChE}$ positive reaction product in the ipsilateral neocortex (Fig. 1). Loss of AChE staining included both motor and somatosensory cortices, but abruptly stopped at the anterior cingulate gyrus which has been shown to receive its cholinergic innervation from the vertical limb of the diagonal band ${ }^{44}$. Animals which received a second lesion to the magnocellular preoptic nucleus showed additional depletion of AChE in the basolateral amygdaloid nucleus. In some animals caudal sections were obtained through nbM itself. In these animals loss of AChEpositive neurons was observed in the lesioned nbM. In animals that had received sham lesions to the nbM there was no apparent decrease of AChE staining (not shown) in either cerebral cortex or nbM.

Scatchard analyses of $\mathrm{L}-\left[{ }^{3} \mathrm{H}\right]$ glutamate binding in Tris$\mathrm{HCl}$ buffer in layers I and II of the somatosensory cortex of the non-lesioned side 1 week following surgery revealed a single binding site with a $B_{\max }$ of $18 \pm 2.1$ $\mathrm{pmol} / \mathrm{mg}$ protein and $K_{\mathrm{d}}$ of $320 \pm 60 \mathrm{nM}$ (Fig. 2). On the lesion side the $B_{\max }$ was $18 \pm 2.0 \mathrm{pmol} / \mathrm{mg}$ protein and the $K_{\mathrm{d}} 310 \pm 40 \mathrm{nM}$. These values were not statistically different. Scatchard analyses of $\mathrm{L}-\left[{ }^{3} \mathrm{H}\right]$ glutamate binding in layers $V$ and VI, were also carried out (Fig. 3). Ipsilateral to the lesion, $\left[{ }^{3} \mathrm{H}\right]$ glutamate binding revealed a single site with a $B_{\max }$ of $10 \pm 3.3 \mathrm{pmol} / \mathrm{mg}$ protein and $K_{\mathrm{d}}$ of $280 \pm 56 \mathrm{nM}$. These values are not statistically 

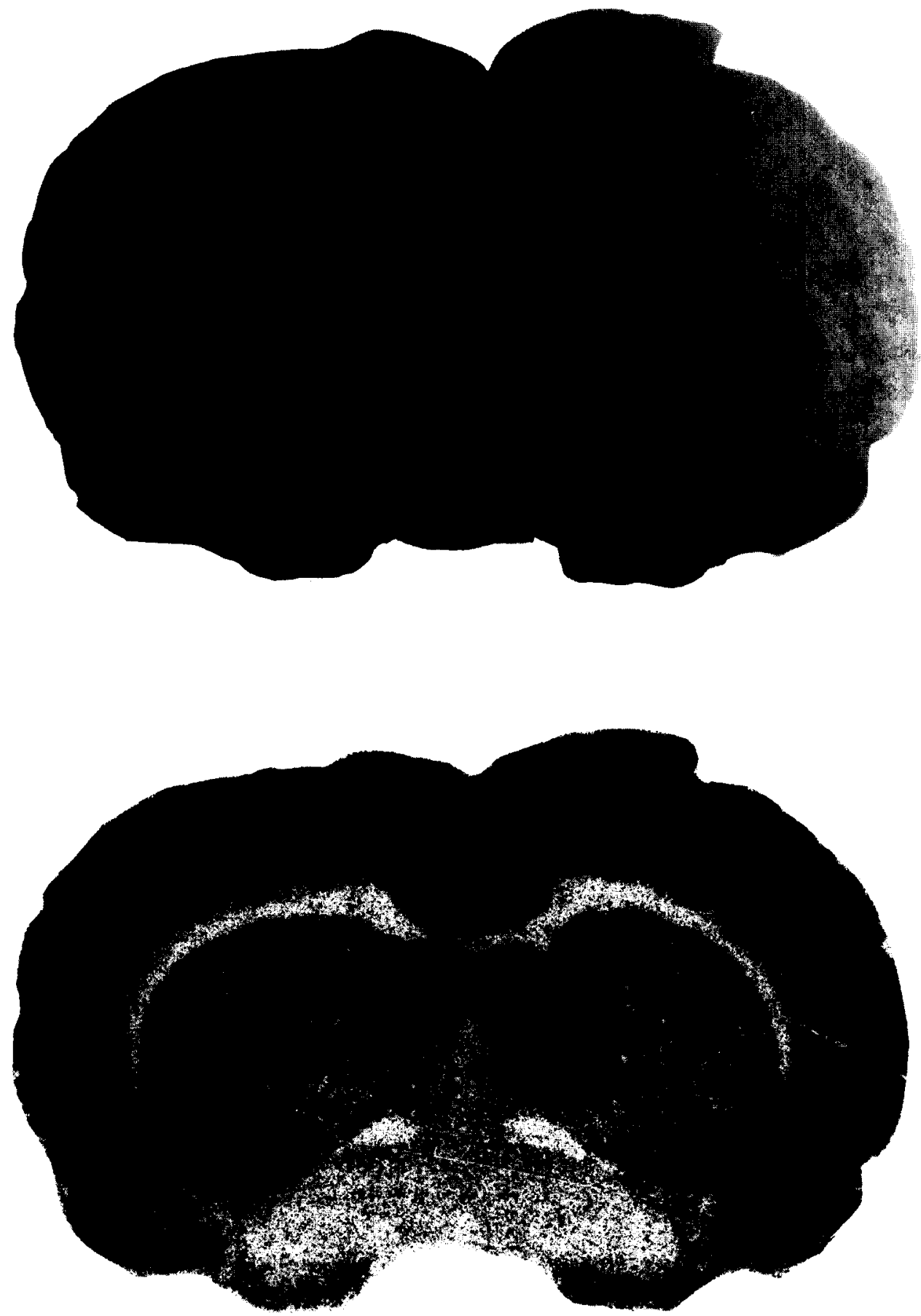

Fig. 1. Adjacent cryostat sections taken from nbM-lesioned rat and processed for acetylcholinesterase histochemistry (top) and total $\left[{ }^{3} \mathrm{H}\right]$ glutamate binding (bottom).

different from the contralateral side in which $B_{\max }$ equalled $12 \pm 3.8 \mathrm{pmol} / \mathrm{mg}$ and $K_{\mathrm{d}}$ equalled $300 \pm 26$ nM.

While the fiber projections of nbM project to all parts of the ipsilateral neocortex ${ }^{2,12,31,44,55}$ contralateral projections may also exist ${ }^{68}$. In an effort to preclude the possibility that no side to side changes were observed due to an underestimation of the bilaterality of nbM efferents, the total binding of $\left[{ }^{3} \mathrm{H}\right]$ glutamate was measured in the ipsilateral cortex of rats 1 week following lesions to the nbM and compared to total binding in the cortex of 8 rats which received sham lesions to nbM 1 week previously. In the control group, the $B_{\max }$ (determined in Tris- $\mathrm{HCl}$ buffer) was $21 \pm 5.6 \mathrm{pmol} / \mathrm{mg}$ protein and the $K_{\mathrm{d}} 290 \pm 107 \mathrm{nM}$. These values were not statistically different from those obtained in the cortex ipsilateral to nbM lesions.

Total $\left[{ }^{3} \mathrm{H}\right]$ glutamate binding in layers $\mathrm{I}$ and $\mathrm{II}$ and $\mathrm{V}$ 


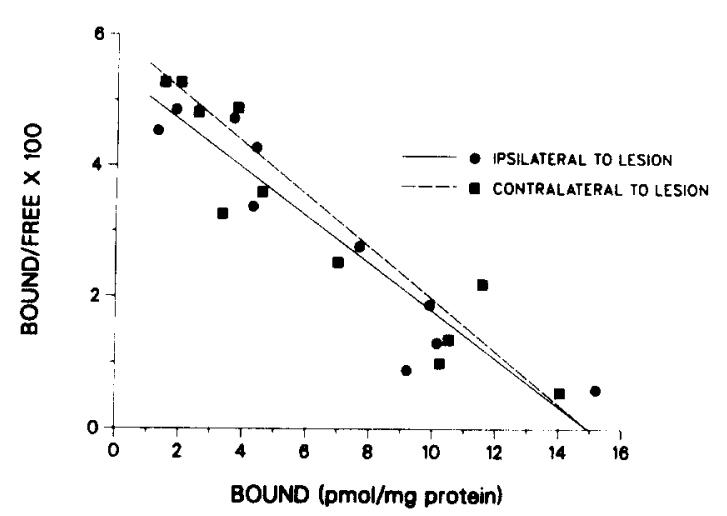

Fig. 2. Representative Scatchard plot of $\left[{ }^{3} \mathrm{H}\right]$ glutamate binding in cortical layers I and II of rat somatosensory cortex 1 week following nbM lesion. Binding assays were carried out in $50 \mathrm{mM}$ Tris- $\mathrm{HCl}$ as described in Materials and Methods. Each point represents specific binding (average of 15 densitometric readings minus readings from nearly adjacent sections in the presence of $1 \mathrm{mM}$ glutamate).

and VI was also evaluated 1 and 2 months following unilateral nbM lesions (Fig. 4). At each time point, no significant changes were observed in $B_{\max }$ between the lesioned and non-lesioned side in the respective layers. There was also no change in affinity constants of $\left[{ }^{3} \mathrm{H}\right]$ glutamate over time (not shown).

Quisqualic acid displacement of $\left[{ }^{3} \mathrm{H}\right]$ glutamate has been demonstrated to reveal high- and low-affinity sites in the rat and human brain ${ }^{19}$. The high-affinity quisqualate site is pharmacologically compatible with a combination of the ionotropic quisqualate (AMPA, $\pm-\alpha-$ amino-3-hydroxy-5-methyl-4-isoxazoleproprionic acid) and the quisqualate-sensitive receptor linked to inositol

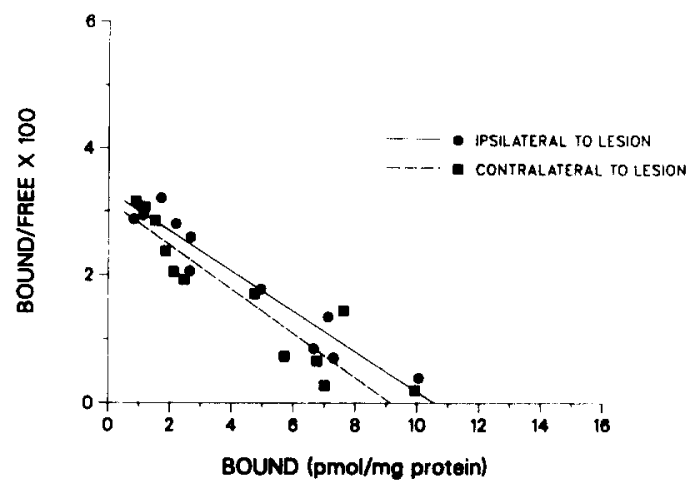

Fig. 3. Representative Scatchard plot of $\left[{ }^{3} \mathrm{H}\right]$ glutamate binding in cortical layers $\mathrm{V}$ and VI of rat somatosensory cortex 1 week following nbM lesion. Binding assay was carried out as in Fig. 2.

phospholipid metabolism ${ }^{5.75}$. The low-affinity quisqualate site is pharmacologically and anatomically most similar to that of the NMDA receptor. In cortical layers I and II ipsilateral to the nbM lesions, there were approximately twice the number of low-affinity sites as there were high-affinity sites. This proportion was identical to that of the non-lesioned side (Fig. 5; Table II). Moreover, there was no significant difference in the absolute number of high- and low-affinity sites nor was there a difference in the affinity of the high $\left(K_{\mathrm{H}}\right)$ and low $\left(K_{\mathrm{L}}\right)$ affinity sites between the two sides (Table II).

Since there was no change in total glutamate binding up to two months following nbM lesions, single point assays on adjacent sections comparing $\left[{ }^{3} \mathrm{H}\right]$ glutamate binding to NMDA receptors and $\left[{ }^{3} \mathrm{H}\right] \mathrm{TCP}$ binding were carried out on tissue 1 week post lesion. No difference in

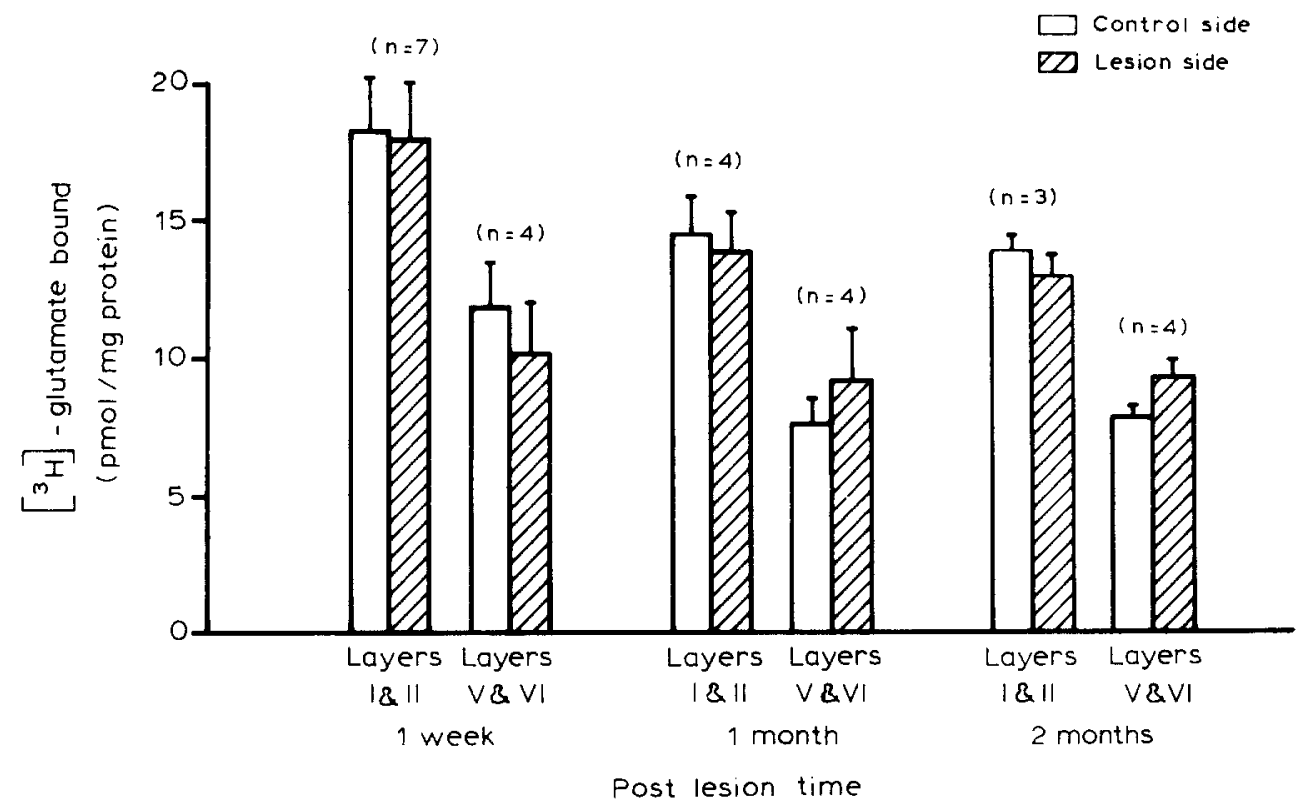

Fig. 4. Histogram of $B_{\max }$ values of $\left[{ }^{3} \mathrm{H}\right]$ glutamate binding one week, one month, and two months following nbM lesions. $B_{\max }$ values (in $\mathrm{pmol} / \mathrm{mg}$ protein) were determined from Scatchard curves generated from saturation experiments carried out in $50 \mathrm{mM}$ Tris- $\mathrm{HCl}$, and thus represent total binding. 
TABLE II

Quisqualic acid displacement of $\left.l^{3} \mathrm{H}\right]$ glutamate binding in cortical layers I and II in nbM-lesioned rats*

Values are means \pm S.E.M.

\begin{tabular}{lcccccc}
\hline & $K_{H}(n M)$ & $K_{L}(\mu M)$ & $B_{H}(p m o l)$ & $B_{L}(p m o l)$ & $\% H$ & $\% L$ \\
\hline Non-lesioned side & $326 \pm 199$ & $254 \pm 47$ & $7.88 \pm 1.5$ & $9.72 \pm 1.35$ & 45 & 55 \\
Lesioned side & $99.57 \pm 83$ & $131 \pm 15$ & $7.48 \pm 0.68$ & $13.5 \pm 1.5$ & 36 & 64 \\
\hline
\end{tabular}

${ }^{*} n=9$.

binding to either receptor in the cortex was observed when the lesioned side was compared to the non-lesioned side (Table III).

\section{Cortical lesions}

Analysis of Cresyl violet-stained cryostat sections taken through the lesion site revealed regions of neuronal loss without tissue necrosis in 6 brains (not shown). Both large- and medium-size neurons were absent and replaced by glial elements. These areas extended ventrally beyond the central zone of the lesion and invariably included layers $\mathrm{V}$ and VI. AChE staining remained intact in the ventral laminae of the cortex on sections adjacent to these used in binding assays. Densitometric analysis was thus confined to layers $\mathrm{V}$ and VI. When bound values of NMDA and TCP receptors on the lesioned side were compared to layers $\mathrm{V}$ and $\mathrm{VI}$ of the non-lesioned side, a greater than $90 \%$ reduction of both receptors was observed (Table III).

\section{Entorhinal knife cuts}

Eight animals received knife cuts to the angular

\section{TABLE III}

$\left.I^{3} H\right]$ Glutamate binding to NMDA receptors and $\left.{ }^{3} H\right] T C P$ binding following selective cortical and subcortical lesions

Values are means \pm S.E.M.

\begin{tabular}{|c|c|c|}
\hline \multirow[t]{2}{*}{ Lesion } & \multicolumn{2}{|l|}{ Receptor } \\
\hline & $\begin{array}{l}\text { NMDA } \\
\text { (pmollmg protein) }\end{array}$ & $\begin{array}{l}\left.l^{3} \mathrm{H}\right] \mathrm{TCP} \\
\text { (pmollmg protein) }\end{array}$ \\
\hline \multicolumn{3}{|l|}{$n b M$} \\
\hline Contralateral & $2.77 \pm 0.22$ & $0.25 \pm 0.01$ \\
\hline Ipsilateral & $2.71 \pm 0.26$ & $0.25 \pm 0.02$ \\
\hline \multicolumn{3}{|l|}{ Cortical } \\
\hline Contralateral & $1.34 \pm 0.26$ & $0.095 \pm 0.007$ \\
\hline $\begin{array}{l}\text { Ipsilateral } \\
\text { Entorhinal }\end{array}$ & $0.11 \pm 0.067^{* *}$ & $0.001 \pm 0.007^{* * *}$ \\
\hline Contralateral & $4.38 \pm 0.21$ & $0.35 \pm 0.02$ \\
\hline Ipsilateral & $3.99 \pm 0.26$ & $0.32 \pm 0.02^{*}$ \\
\hline \multicolumn{3}{|l|}{ Dentate } \\
\hline Contralateral & $4.1 \pm 0.234$ & $0.25 \pm 0.022$ \\
\hline Ipsilateral & $0.67 \pm 0.205^{* * *}$ & $0.02 \pm 0.01^{* * *}$ \\
\hline
\end{tabular}

Student's $t$-test $P$-values: ${ }^{*}<0.05 ;^{* *}<0.01,{ }^{* * *}<0.001$. bundle. Analysis of Cresyl violet stained cryostat sections taken at various dorsoventral levels revealed complete separation of the entorhinal cortex from the hippocampal formation in approximately the dorsal $3 / 4$ of the hippocampal formation. Due to the nature of the surgery, the cut never extended through the most ventral and lateral portions of the entorhinal cortex and it is likely that some projections arising from pars lateralis remained intact. The striate and subicular cortices were also interrupted. In no case was there any evidence of damage to the hippocampus proper or the dentate gyrus.

For receptor binding studies, 8 sequential sections were obtained from the dorsal hippocampal formation at a level where the subregions CA1, CA4 and the dentate gyrus could be clearly identified. The first 4 sections were assayed for NMDA receptors and the last 4 sections assayed for $\left[{ }^{3} \mathrm{H}\right] \mathrm{TCP}$ binding. Densitometric readings of the dentate gyrus were taken from these sections in the region corresponding to the outer two thirds of the molecular layer.

Analysis of $\left[{ }^{3} \mathrm{H}\right]$ glutamate binding to NMDA receptors in the control dentate gyrus 1 week following knife cuts revealed that there were $4.38 \pm 0.21 \mathrm{pmol} / \mathrm{mg}$ protein glutamate bound. Ipsilateral to the lesion there was 3.99 $\pm 0.26 \mathrm{pmol} / \mathrm{mg}$ protein glutamate bound. The difference between the lesioned and non-lesioned side was $9 \%$, but

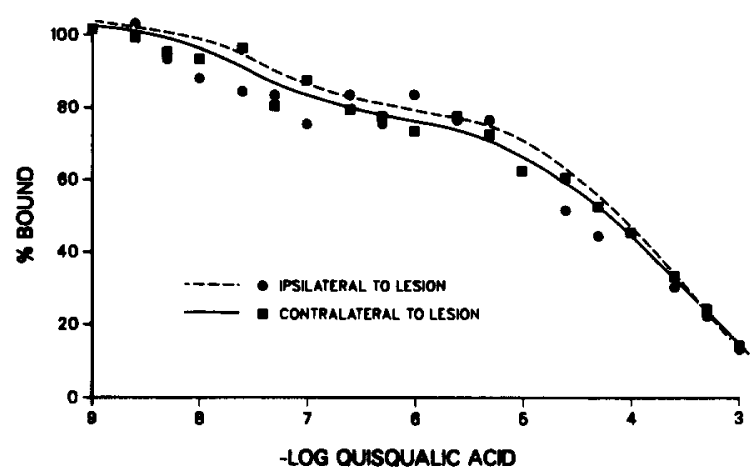

Fig. 5. Quisqualic acid displacement curve of $\left[{ }^{3} \mathrm{H}\right]$ glutamate binding in cortical layers I and II one week following ibotenate lesions to nbM. Competition experiments were conducted as described in text and curves generated using the computer-program LIGAND. Each point represents the averaged specific binding obtained from 9 lesioned animals. 

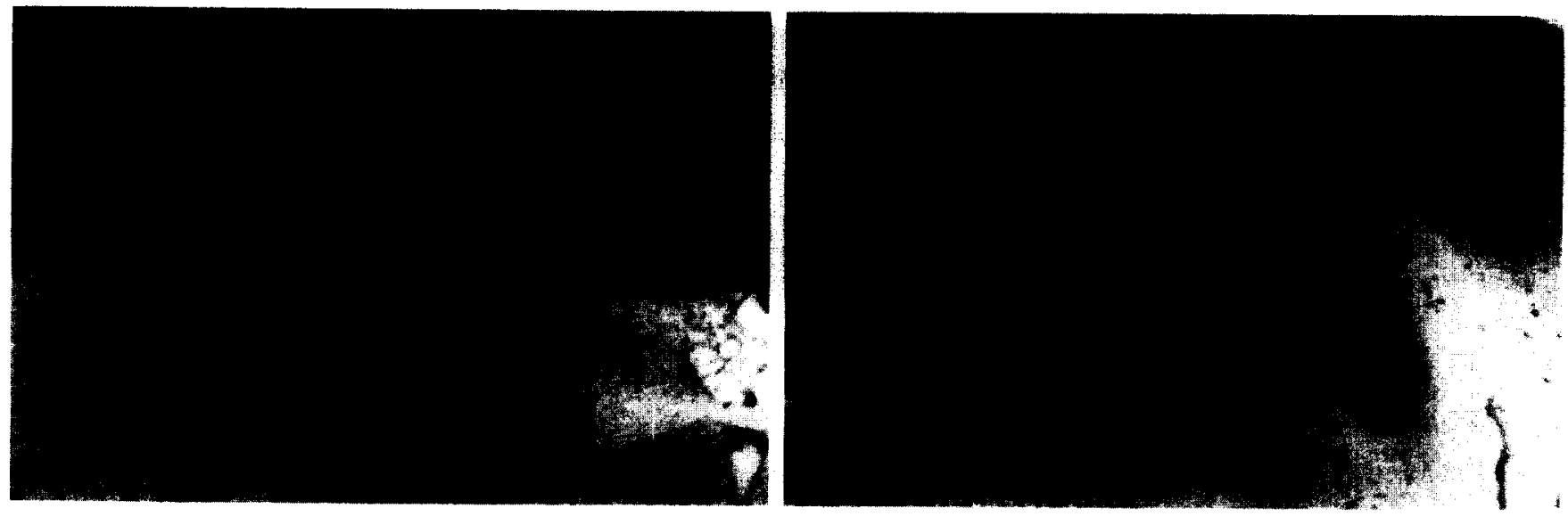

Fig. 6. Low power view of Cresyl violet-stained sections of the hippocampal formation. Left figure,- control side; right figure, lesion (contralateral) side 1 week following injection of colchicine. Note depletion of granule cells in both blades of the dentate gyrus.

not significant. Binding of $\left[{ }^{3} \mathrm{H}\right] \mathrm{TCP}$ also revealed $9 \%$ reduction of binding on the lesioned side, which was statistically significant (Table III).

\section{Dentate gyrus lesions}

One week following application of colchicine, a near total loss of dentate gyrus granule cells was observed on visual inspection. Microscopic visualization under low power supported this finding and also showed marked inflammatory reaction in the region where dentate granule cells existed (Fig. 6). Due to the loss of neurons, there was a narrowing of the space between the stratum oriens of CA1 and stratum oriens of CA4, as well as a reduction in the distance between $\mathrm{CA} 1$ and the dorsal thalamus.

Four sequential sections in each brain were assayed for NMDA receptors and 4 sequential sections assayed for $\left[{ }^{3} \mathrm{H}\right] \mathrm{TCP}$ binding. As with animals with entorhinal knife cuts, densitometric readings of the dentate gyrus were taken from these sections in the outer two-thirds of the molecular layer. When the amount of $\left[{ }^{3} \mathrm{H}\right]$ glutamate binding to the NMDA receptor on the lesioned side was compared to the non-lesioned side of the dentate gyrus, an $84 \%$ reduction was observed (Table III). Similarly, $\left[{ }^{3} \mathrm{H}\right] \mathrm{TCP}$ binding was reduced approximately $92 \%$ in the colchicine-treated dentate gyrus compared to the untreated side (Table III).

\section{DISCUSSION}

In this study the neuronal localization of both NMDAsensitive glutamate and dissociative anesthetic receptors was investigated. Previous studies have indicated that glutamate and compounds like PCP and ketamine regulate the release of cortical ${ }^{34}$ and striatal acetylcholine ${ }^{59}$. Furthermore both receptor types are known to be decreased in the brains of patients who have died with $\mathrm{DAT}^{20,21,39,54}$. Most of the acetylcholine in the cortex is released from the terminals of $n b M$ neurons ${ }^{28}$. Since the nucleus basalis projects widely to the entire cortical mantle ${ }^{2,12,31,44}$ and shows marked cell loss in DAT ${ }^{11,73}$ it was thought that at least some of the cortical NMDA and dissociative anesthetic receptors might be located on $\mathrm{nbM}$ terminals. Thus, the loss of NMDA receptors could be secondary to the degeneration of cholinergic terminals.

Following unilateral lesions to the nucleus basalis no changes were observed in either the total number of glutamate binding sites or their affinities when side to side comparisons were made at one week, two weeks or two months following surgery. Moreover, displacement studies showed that the proportion of high- and lowaffinity quisqualate binding sites remained constant following nbM lesions. The possibility that there was an inadequately placed lesion was ruled out by analyzing the efficacy of the lesion using AChE histochemistry. In addition, comparison of glutamate binding in nucleus basalis-lesioned rats to binding in sham-lesioned rats indicated no change in either the $B_{\max }$ or $K_{\mathrm{d}}$ of glutamate binding. The values of $\left[{ }^{3} \mathrm{H}\right] \mathrm{TCP}$ binding in the cortex, ipsilateral to the lesion were not significantly different from the contralateral cortex and were virtually identical to levels of binding seen in the cortex of normal rats ${ }^{40}$. These findings indicate that neither cortical NMDA nor $\left[{ }^{3} \mathrm{H}\right] \mathrm{TCP}$-labeled receptors exist on presynaptic terminals of cholinergic neurons originating in $\mathrm{nbM}$.

An alternative hypothesis to the presynaptic localization of NMDA and TCP receptors is that they exist on neurons intrinsic to the cerebral cortex. Ibotenic acid lesions made in the cortex resulted in a greater than $90 \%$ reduction of both NMDA (92\%) and PCP (99\%) binding sites. Ibotenic acid is a rigid heterocyclic analogue of glutamate known to make axon-sparing lesions ${ }^{56}$. In this 
study, only regions in which AChE staining remained intact were analyzed, further strengthening the argument that the receptor loss was not due to degeneration of ascending cholinergic terminals. The near total reduction in NMDA and PCP receptors indicates that, at least in the cortex, the NMDA receptor complex exists on intrinsic neurons.

Unlike the cerebral cortex, physiological ${ }^{8}$ and biochemical $^{6}$ studies in the hippocampal formation have suggested that NMDA receptors exist as presynaptic autoreceptors, regulating the release of glutamate from excitatory amino acid nerve endings. To test this latter possibility, binding to both NMDA and dissociative anesthetic receptors was studied in the outer two-thirds of stratum moleculare of the dentate gyrus following knife-cut lesions to the entorhinodentate pathway and following selective destruction of dentate granule cells using colchicine. The dentate gyrus contains a high density of both NMDA and PCP receptors ${ }^{19,40}$. The entorhinal cortex is the origin of a unidirectional projection system ${ }^{60,63}$ which provides the major glutamatergic innervation to the dentate gyrus ${ }^{72}$. Lesions to this pathway have been shown to result in reduction of markers specific for glutamate terminals ${ }^{48,61}$.

One week following knife cuts to this pathway a small (9\%) but significant reduction of $\left[{ }^{3} \mathrm{H}\right] \mathrm{TCP}$ binding was observed. An equally small reduction of NMDA receptors was measured, but this was not significant. This disparity may be due to the increased variance seen in the NMDA assay. These findings are consistent with those recently reported by Ulas et al. ${ }^{66}$ who demonstrated a statistically not significant 'trend towards reduction in NMDA receptor binding levels' in the outer two-thirds of stratum moleculare 1-7 days following ipsilateral entorhinal cortex ablation. On the other hand, the small but significant reduction in TCP binding we observed contrasts with the absence of change in binding of $\left[{ }^{3} \mathrm{H}\right] \mathrm{MK}$ 801 to the PCP site noted by Bekenstein et al. following unilateral entorhinal cortex lesions. This disparity may be due to several factors. Bekenstein et al. ${ }^{1}$ removed afferent input to the dentate gyrus with electrolytic lesions of the entorhinal cortex which may have spared some cells of origin of the entorhinodentate pathway. Additionally, in analyzing their autoradiograms, they densitometrically averaged the area of the entire dorsal blade of the dentate gyrus (which includes the granule cell layer) while we measured a region limited to the outer two-thirds of the dorsal blade of the dentate gyrus. As the reduction we report in PCP receptor number is small, it is possible that this reduction might have been missed due to the dilutional effect of analyzing a larger, less homogenous region.

Destruction of the granule cells, on the other hand, resulted in an almost $90 \%$ reduction of both receptors. Similar but less marked $(50-60 \%)$ reduction in $\left[{ }^{3} \mathrm{H}\right] \mathrm{MK}$ 801 binding was reported by Bekenstein et al. following colchicine administration to the dentate gyrus ${ }^{1}$. Their study, however, used smaller amounts of colchicine per lesion which likely resulted in less complete destruction of the granule cell and subsequently more residual binding. Taken together, it appears that nearly all of the NMDA and TCP receptors in the dentate gyrus exist on granule cell dendrites and that no more than $10 \%$ exist presynaptically as autoreceptors on entorhinodentate glutamate terminals. A predominantly postsynaptic localization of NMDA receptors has also been shown to occur in the CA1 region of the rat hippocampal formation?.

In a previous study by Werling and Nadler, significant reductions (about $45 \%$ ) of binding to glutamate receptors in the dentate gyrus were not observed until almost 3 weeks following destruction of the entorhinal cortex ${ }^{71}$. Werling and Nadler, however, used fresh membrane preparations for binding assays. Since there is a large population of non-NMDA glutamate binding sites detectable in fresh but not frozen tissue ${ }^{14}$, it is likely that the receptors they described were non-NMDA. Nevertheless, since it had been shown that dendritic spines degenerated in the dentate gyrus 1 week following lesions to entorhinal cortex ${ }^{4,52}$, these authors concluded that the population of glutamate receptors they analyzed existed postsynaptically. This seems unlikely however, since at 3 weeks, reacquisition of spines to control levels may have been almost complete ${ }^{4,52}$.

It has been argued that NMDA receptors exist on astrocytes and that alterations in NMDA binding following lesions may parallel quantitative changes in glial elements. In a recent study by Greenamyre and Young ${ }^{22}$, quinolinic acid lesions in the rat striatum resulted in a $92 \%$ reduction of NMDA binding. Quinolinic acid is an endogenous metabolite of tryptophan that selectively destroys neurons ${ }^{57}$. In the rat striatum, cell loss results in a marked inflammatory response with gliosis that is evident at 7 days after quinolinate application and persists up to one year ${ }^{3}$. If the NMDA receptor complex exists on glial cells, then one would not have expected such a marked reduction in NMDA binding during a period of glial proliferation.

In this study, we have shown that the NMDA receptor complex exists predominantly on either the cell bodies or dendrites of neurons intrinsic to the cortex and hippocampal formation. In Alzheimer's disease, there is extensive loss of pyramidal neurons in both of these regions ${ }^{49,64}$. Studies using the Golgi technique have indicated that these neurons project apical and basilar dendrites to precisely those layers in which NMDA 
receptor loss is greatest ${ }^{36.37}$. In Alzheimer's disease, retraction of dendritic spines ${ }^{38.43}$ and cell loss ${ }^{49.64}$ in these layers may account for the observed reductions of NMDA receptors.

\section{REFERENCES}

1 Bekenstein, J.W., Bennett, J.P., Wooten, G.F. and Lotham, E.W. Autoradiographic evidence that NMDA receptor-coupled channels are located postsynaptically and not presynaptically in the perforant path-dentate granule cell system of the rat hippocampal formation, Brain Research, 514 (1990) 334-342.

2 Bigl V., Woolf, N.J. and Butcher, L.L., Cholinergic projections from the basal forebrain to frontal, parietal, temporal, occipital, and cingulate cortices: a combined fluorescent tracer and acetylcholinesterase analysis, Brain Res. Bull., 8 (1982) 727-749.

3 Björklund, H., Olson, L., Dahl, D. and Schwarcz, R., Shortand long-term consequences of intracranial injections of the excitotoxin, quinolinic acid, as evidenced by GFA immunohistochemistry of astrocytes, Brain Research, 371 (1986) 267-277.

4 Caceres, A. and Steward, O., Dendritic reorganization in the denervated dentate gyrus of the rat following entorhinal cortical lesions: a Golgi and electron microscopic analysis, $J$. Comp. Neurol., 214 (1983) 387-403.

5 Cha, J.H.J., Makowiec, R.L., Penney, J.B. and Young, A.B., $\mathrm{L}-\left[{ }^{3} \mathrm{H}\right]$ Glutamate labels the metabotropic excitatory amino acid receptor in rodent brain, Neurosci. Lett., 113 (1990) 78-83.

6 Chapman, A.G. and Bowker, H.M., Inhibition of hippocampal ${ }^{3} \mathrm{H}$-D-aspartate release by 2 -APB, 2-APV and 2-APH. In: T.P. Hicks, D. Lodge and H. McLennan (Eds.), Excitatory Amino Acid Transmission, Neurology and Neurobiology, Vol. 24, Alan R. Liss, New York, 1987, pp. 165-168.

7 Chu, D.C.M., Maragos, W.F., Penney, J.B. and Young, A.B., Magnesium ions increase binding affinity of dissociative anesthetic receptors but not of NMDA receptors in rat brain. In E.A. Cavalheiro, J. Lehmann and L. Turski (Eds.), Frontiers in Excitatory Amino Acid Research, Neurology and Neurobiology, Vol. 46, Alan R. Liss, New York, 1988, pp. 567-570.

8 Collingridge, G.L., Kehl, S.J. and McLennan, H., Excitatory amino acids in synaptic transmission in the Schaffer collateralcommissural pathway of the rat hippocampus, J. Physiol., 334 (1983) 33-46.

9 Crepel, V., Represa, A. and Ben-Ari, Y. Effect of ischemia and intra-amygdaloid kainate injection on the density of NMDA binding sites in the hippocampal CA1 region, Eur. J. Pharmacol., 151 (1988) 355-356.

10 Czuczwar, S.J. and Meldrum, B., Protection against chemically induced seizures by 2-amino-7-phosphonoheptanoic acid, Eur. $J$. Pharmacol., 83 (1982) 335-338.

11 Davies, P. and Maloney, A.J.F., Selective loss of central cholinergic neurons in Alzheimer's disease, Lancet, 2 (1976) 1403.

12 Divac, I., Magnocellular nuclei of the basal forebrain project to neocortex, brain stem, and olfactory bulb. Review of some functional correlates, Brain Research, 93 (1975) 385-398.

13 Duchen, M.R., Burton, N.R. and Biscoe, T.J., An intracellular study of the interactions of $N$-methyl-D-aspartate with ketamine in the mouse hippocampal slice, Brain Research, 342 (1985) 149-153.

14 Fagg, G.E., Mena, E.E., Monaghan, D.T. and Cotman, C.W., Freezing eliminates a specific population of L-glutamate receptors in synaptic membranes, Neurosci. Lett., 38 (1983) 157-162.

15 Flatman, J.A., Schwindt, P.C., Crill, W.E. and Stafstrom, C.E., Multiple actions of $N$-methyl-D-aspartate on cat neocortical neurons in vitro, Brain Research, 266 (1983) 169-173.

16 Fonnum, F., A rapid radiochemical method for the determination of choline acetyltransferase, J. Neurochem., 24 (1975) 407-409.

17 Gibbs, R.B., Harris, E.W. and Cotman, C.W., Replacement of damaged cortical projections by homotypic transplants of entorhinal cortex, J. Comp. Neurol., 237 (1985) 47-64.
Acknowledgements. We would like to thank Genell Fries, Suyin Liang and Catherine Leggieri for preparation of the manuscript and Kevin O'Mara and Zane Hollingsworth for technical assistance. This study was supported by USPHS Grants P50AGO8671 and NS19613.

18 Goldschmidt, R.B. and Steward, O., Preferential neurotoxicity of colchicine for granule cells of the dentate gyrus of the adult rat, Proc. Natl. Acad. Sci. U.S.A., 17 (1980) 3047-3051.

19 Greenamyre, J.T., Olson, J.M.M., Penney Jr., J.B. and Young, A.B., Autoradiographic characterization of $N$-methyl-baspartate-, quisqualate- and kainate-sensitive glutamate binding sites. J. Pharmacol. Exp. Ther., 233 (1985) 254-263.

20 Greenamyre, J.T., Penney, J.B., Young, A.B., D'Amato, C.J., Hicks, S.P. and Shoulson, I., Alterations in L-glutamate binding in Alzheimer's and Huntington's diseases, Science, 227 (1985) 1496-1499.

21 Greenamyre, J.T., Penney J.B., D'Amato, C.J. and Young, A.B., Dementia of the Alzheimer's type: changes in hippocampal L. $\left[{ }^{3} \mathrm{H}\right]$ glutamate binding. J. Neurochem., 48 (1987) 543-551.

22 Greenamyre, J.T. and Young, A.B., Synaptic localization of striatal NMDA, quisqualate and kainate receptors, Neurosci. Lett., 101 (1989) 133-137.

23 Hagberg, H., Andersson, P., Butcher, S., Sandberg, M.. Lehmann A. and Hamberger, A., Blockade of $N$-methylD-aspartate-sensitive acidic amino acid receptors inhibits ischemia-induced accumulation of purine catabolites in the rat striatum, Neurosci. Lett., 68 (1986) 311-316.

24 Harris. E.W., Ganong, A.H. and Cotman, C.W., Long-term potentiation in the hippocampus involves activation of $N$-methylD-aspartate receptors, Brain Research, 323 (1984) 132-137.

25 Harrison, N.L. and Simmonds, M.A., Quantitative studies on some antagonists of $N$-methyl-D-aspartate in slices of rat cerebral cortex, Br. J. Pharmacol., 84 (1985) 381-191.

26 Herron, C.E., Williamson, R. and Collingridge, G.L., A selective $N$-methyl-D-aspartate antagonist depresses epileptiform activity in rat hippocampal slices, Neurosci. Lett., 61 (1985) 255-260.

27 Johnston, M.V.. McKinney, M. and Coyle, J.T., Evidence for a cholinergic projection to neocortex from neurons in basal forebrain, Proc. Natl. Acad. Sci. U.S.A., 76 (1979) 5392-5396.

28 Johnston, M.V., McKinney, M. and Coyle, J.T., Neocortical cholinergic innervation: a description of extrinsic and intrinsic components in the rat. Exp. Brain Res., 43 (1981) 159-172.

29 Karnovsky, M.J. and Roots, L., A 'direct-coloring' thiocholine method for cholinesterases, J. Histochem. Cytochem., 12 (1964) 219-221.

30 Kushner, L., Lerma, J., Zukin, R.S., and Bennett, M.V.L., Coexpression of $N$-methyl-D-aspartate and phencyclidine receptors in Xenopus oocytes injected with rat brain mRNA, Proc. Natl. Acad. Sci. U.S.A., 85 (1988) 3250-3254.

31 Lehmann, J., Nagy, J.I., Atmadja, S. and Fibiger, H.C., The nucleus basalis magnocellularis: the origin of a cholinergic projection to the neocortex of the rat, Neuroscience, 5 (1980) $1161-1174$.

32 Lerma, J., Kushner, L., Spray, D.C., Bennett. M.V.L. and Zukin, R.S., mRNA from NCB-20 cells encodes the $N$ methyl-D-aspartate/phencyclidine receptor: a Xenopus oocyte expression study, Proc. Natl. Acad. Sci. U.S.A., 86 (1989) $1708-1711$

33 Lodge, D. and Anis, N.A., Effects of phencyclidine on excitatory amino acid activation of spinal interneurons in the cat, Eur. J. Pharmacol., 77 (1982) 203-204.

34 Lodge, D. and Johnston, G.A.R., Effect of ketamine on amino acid-evoked release of acetylcholine from rat cerebral cortex in vitro, Neurosci. Lett., 56 (1985) 371-375.

35 Loo, P., Braunwalder, A., Lehman, J. and Williams, M., Radioligand binding to centeral phencyclidine sites is dependent 
on excitatory amino acid receptor agonists, Eur. J. Pharmacol., 123 (1986) 467-468.

36 Lorente de No, R., Studies on the structure of the cerebral cortex. The area entorhinalis, J. Psychol. Neurol., 45 (1933) 381-438.

37 Lorente de No, R., Studies on the stucture of the cerebral cortex. Continuation of the study of the ammonic system, $J$. Psychol. Neurol., 46 (1934) 113-177.

38 Mann, D.M.A., Yates, P.O. and Marcyniuk, B., Some morphometric observations on the cerebral cortex and hippocampus in presenile Alzheimer's disease, senile dementia of the Alzheimer type and Down's syndrome in middle age, $J$. Neurol. Sci., 69 (1985) 139-159.

39 Maragos, W.F., Chu, D.C.M., Young, A.B., D'Amato, C.J. and Penney, J.B., Loss of hippocampal $\left[{ }^{3} \mathrm{H}\right] \mathrm{TCP}$ binding in Alzheimer's disease, Neurosci. Lett., 74 (1987) 371-376.

40 Maragos, W.F., Penney, J.B. and Young, A.B., Anatomic correlation of NMDA and ${ }^{3} \mathrm{H}-\mathrm{TCP}$-labeled receptors in rat brain, J. Neurosci., 8 (1988) 493-501.

41 Martin D. and Lodge, D., Ketamine acts as a non-competitive $\mathrm{N}$-methyl-D-aspartate antagonist on frog spinal cord in vitro, Neuropharmacology, 24 (1985) 999-1003.

42 McKernan, R.M., Castro, S., Poat, J.A. and Wong, E.H.F., Solubilization of the $N$-methyl-D-aspartate receptor channel complex from rat and porcine brain, J. Neurochem., 52 (1989) 777-785.

43 Mehraein P., Yamada, M. and Tarnowska-Dziduszko, E., Quantitative study on dendrites and dendritic spines in Alzheimer's disease and senile dementia. In G.W. Kreutzberg (Ed.), Advances in Neurology, Vol. 12, Raven Press, New York, 1975, pp. 453-458.

44 Mesulam, M.-M., Mufson, E.J., Wainer, B.H. and Levey, A.I., Central cholinergic pathways in the rat: an overview based on an alternative nomenclature (Ch1-Ch6), Neuroscience, 10 (1983) 1185-1201.

45 Monaghan, D.T. and Cotman, C.W., Distribution of $N$-methylD-aspartate-sensitive $\mathrm{L}-\left[{ }^{3} \mathrm{H}\right]$ glutamate-binding sites in rat brain, J. Neurosci., 5 (1985) 2909-2919.

46 Morris, G.M., Anderson, E., Lynch, G.S. and Baudry, M. Selective impairment of learning and blockade of long-term potentiation by an $\mathrm{N}$-methyl-D-aspartate receptor antagonist, AP5, Nature, 319 (1986) 774-776.

47 Munson, P.J. and Rodbard, D., Ligand: a versatile computerized approach for characterization of ligand-binding systems, Anal. Biochem., 107 (1980) 220-239.

48 Nadler, J.V., Vaca, K.W., White, W.F., Lynch, G.S. and Cotman, C.W., Aspartate and glutamate as possible transmitters of excitatory hippocampal afferents, Nature, 260 (1976) 538-541

49 Neary, D., Snowden, J.S., Mann, D.M.A., Bowen, D.M., Sims, N.R., Northen, B., Yates, P.O. and Davison, A.N., Alzheimer's disease: a correlative study, J. Neurol. Neurosurg. Psychiatry, 49 (1986) 229-237.

50 Olney, J.W., Price, M.T., Fuller, T.A., Labruyere, J., Samson, L., Carpenter, M. and Mahan, K., The anti-excitotoxic effects of certain anesthetics, analgesics and sedative-hypnotics, $\mathrm{Neu}$ rosci. Lett., 68 (1986) 29-34.

51 Pan, H.S., Frey, K.A., Young, A.B. and Penney Jr., J.B., Changes in $\left[{ }^{3} \mathrm{H}\right]$ muscimol binding in substantia nigra, entopeduncular nucleus, globus pallidus, and thalamus after striatal lesions as demonstrated by quantitative receptor autoradiography, J. Neurosci., 3 (1983) 1189-1198.

52 Parnavelas, J.G., Lynch, G., Brecha, N., Cotman, C.W. and Globus, A., Spine loss and regrowth in hippocampus following deafferentation, Nature, 248 (1974) 71-73.

53 Paxinos, G. and Watson, C., The Rat Brain in Stereotaxic Coordinates, Academic Press, New York, 1982.

54 Penney, J.W., Maragos, W., Greenamyre, J.T., Debowey, D.L., Hollingsworth, Z. and Young, A.B., Excitatory amino acid binding sites in the hippocampal region of Alzheimer's disease and other dementias, J. Neurol. Neurosurg. Neuropsychiatry, 53
(1990) 314-320.

55 Saper, C.B., Organization of cerebral cortical afferent systems in the rat. II. Magnocellular basal nucleus, J. Comp. Neurol., 222 (1984) 313-342.

56 Schwarcz, R., Hökfelt, T., Fuxe, K., Jonsson, G., Goldstein, M. and Terenius, $\mathbf{L}$., Ibotenic acid-induced neuronal degeneration: a morphological and neurochemical study, Exp. Brain Res., 37 (1979) 199-216.

57 Schwarcz, R., Whetsell Jr., W.O. and Mangano, R.M., Quinolinic acid: an endogenous metabolite that produces axon-sparing lesions in rat brain, Science, 219 (1983) 316-318.

58 Simon, R.P., Swan, J.H., Griffiths, T. and Meldrum, B.S., Blockade of $N$-methyl-D-aspartate receptors may protect against ischemic damage in the brain, Science, 226 (1984) $850-852$

59 Snell, L.D. and Johnson, K.M., Characterization of the inhibition of excitatory amino acid-induced neurotransmitter release in the rat striatum by phencyclidine-like drugs, J. Pharmacol. Exp. Ther., 238 (1986) 938-946.

60 Steward, O., Topographic organization of the projections from the entorhinal area to the hippocampal formation of the rat, $J$. Comp. Neurol., 167 (1976) 285-314.

61 Storm-Mathisen, J., Glutamic acid and excitatory nerve endings: reduction of glutamic acid uptake after axotomy, Brain $R e$ search, 120 (1977) 379-386.

62 Stringer, J.L., Greenfield, L.J., Hackett, J.T. and Guyenet, P.G., Blockade of long-term potentiation by phencyclidine and opiates in the hippocampus in vivo and in vitro, Brain Research, 280 (1983) 127-138.

63 Swanson, L.W. and Cowan, W.M., An autoradiographic study of the organization of the efferent connections of the hippocampal formation in the rat, J. Comp. Neurol., 172 (1977) 49-84.

64 Terry, R.D., Peck, A., DeTeresa, R., Schechter, R. and Horoupian, D.S., Some morphometric aspects of the brain in senile dementia of the Alzheimer type, Ann. Neurol., 10 (1980) 184-192.

65 Thomson, A.M., West, D.C. and Lodge, D., An $N$-methylaspartate receptor-mediated synapse in rat cerebral cortex: a site of action of ketamine?, Nature, 313 (1985) 479-481.

66 Ulas, J., Monaghan, D.T. and Cotman, C.W., Plastic response of hippocampal excitatory amino acid receptors to deafferentation and reinnervation, Neuroscience, 34 (1990) 9-17.

67 Verdoorn, T.A., Kleckner, N.W. and Dingledine, R., Rat brain $N$-methyl-D-aspartate receptors expressed in Xenopus oocytes, Science, 238 (1987) 1114-1116.

68 Walker, L.C., Kitt, C.A., DeLong, M.R. and Price, D.L. Noncollateral projections of basal forebrain neurons to frontal and parietal neocortex in primates, Brain Res. Bull., 15 (1985) 307-314

69 Weiss, J., Goldberg, M.P. and Choi, D.W., Ketamine protects cultured neocortical neurons from hypoxic injury, Brain $R e$ search, 380 (1986) 186-190.

70 Wenk, H., Bigl, V. and Meyer, U., Cholinergic projections from magnocellular nuclei of the basal forebrain to cortical areas in rats, Brain Res. Rev., 2 (1980) 295-316.

71 Werling, L.L. and Nadler, J.V., Evidence for differential localization of two binding sites for $\mathrm{L}-\left[{ }^{3} \mathrm{H}\right]$ glutamate in rat fascia dentata, Brain Research, 276 (1983) 344-347.

72 White, W.F., Nadler, J.V., Hamberger, A., Cotman, C.W. and Cummings, J.T., Glutamate as transmitter of hippocampal perforant path, Nature (London), 270 (1977) 356-357.

73 Whitehouse, P.J., Price, D.L., Struble, R.G., Coyle, J.T. and DeLong, M.R., Alzheimer's disease and senile dementia: loss of neurons in the basal forebrain, Science, 215 (1982) 1237-1239.

74 Wieloch T., Hypoglycemia-induced neuronal damage prevented by an $N$-methyl-D-aspartate antagonist, Science, 230 (1985) 681-683.

75 Young, A.B. and Fagg, G.E., Excitatory amino acid receptors in the brain: membrane binding and receptor autoradiographic approaches, TIPS, 11 (1990) 126-133.

76 Zilles, K., The Cortex of the Rat: a Stereotaxic Atlas, Springer, New York, 1985. 